\title{
THE STUDENTS' ATTITUDE TOWARDS ENGLISH CLASSROOM ENVIRONMENT OF MADRASAH TSANAWIYAH NEGERI MODEL MAKASSAR 2018/2019
}

\author{
Hanafi Pelu \\ Balai Diklat Keagamaan Makassar \\ Email: hanafipelu@gmail.com
}

\begin{abstract}
This research aims to find out the students' attitude toward English classroom environment especially English teacher, English material and English classroom management. This research used descriptive method to find out the student's attitude toward English teacher, English material and English classroom environment. The population of this research was the second-year students MTS Negeri Model Makassar. The sample technique of this study was random sampling which consists of 50 students.

The instrument of this research was questionnaire by using mean score to find out the mean score of them $x^{-}=n 1(x 1+x 2+50+x n)$. The result of data analysis of the questionnaire indicated that the students have positive attitude toward English teacher (59. $24 \%)$, the students have positive attitude towards English material (53. $64 \%$ ) and the students have neutral attitude toward English classroom management (39\%).
\end{abstract}

Keywords: students attitude, teacher, english material, english classroom management

\section{INTRODUCTION}

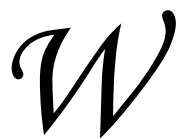

e all know that language is one of the vital means of communication for people all over the world. We can express our ideas to other by the language. The ability to understand and use language is a human trait that, like a good health, we take for granted until something goes wrong. Language is the means to organize our thoughts and present them in mutually agreed upon fashions that allow us as speakers to share our thought with listeners.

Human beings can communicate with each other. We are able to exchange knowledge, beliefs, opinions, wishes, threats, commands, thanks, promises, declarations, feelings-only our imagination sets limits. We can laugh to express amusement, happiness, or disrespect, we can smile to express amusement, pleasure, approval, or bitter feelings, we can shriek to express anger, excitement, or fear, we can clench our fists to express determination, anger or a threat, we can raise our eyebrows to express surprise or disapproval, and so on, but our system of communication before anything else is language. In this book we shall tell you a lot about language, but as a first step towards a definition we can say that it is a system of communication based upon words and the combination of 
words into sentences. Communication by means of language may be referred to as linguistic communication, the other ways mentioned abovelaughing, smiling, shrieking, and so on -are types of non-linguistic communication.

Language permits us to express our basic needs. It provides a varied through which we can learn about the word and foster our functioning as social being. So it is not wrong if we say that we need to study language for whatever reasons whether it is local language, national or international language as a language of unifier in this world.

Language is a system that consists of the development, acquisition, maintenance and use of complex systems of communication, particularly the human ability to do so; and a language is any specific example of such a system, Wikipedia, 2016: 10.

Language is a system of conventional spoken, manual, or written symbols by means of which human beings, as members of a social group and participants in its culture, express themselves. The functions of language include communication, the expression of identity, play, imaginative expression, and emotional release, David Crystal and Robert Henry Robins 2018: 1.

The explanations above are of the reasons that English is taught in our country. The Government has made decision that English is the first foreign language to be taught in Indonesia as compulsory subject in the school. By the end of junior high school, students will have skills of reading, listening, speaking, writing and grammar. In this case, another thing that must be considered is that to make students interest to learn, there are many factors that influence the learning process, including where the learning process take places. Especially in the classroom, we know environment characteristic, namely the teacher, the material, the management of the classroom, the students, the physical condition of the classroom, and the climate of the classroom.

Related to the place, particularly the classroom we sometimes hear recurring expression from the students. They commit that some classroom are dull, depression even terrifying. So, we probably agree that good classroom environment is an essential intergradient successful of teaching as Jacobofits in Sahabuddin (1994) states that one of the factors that influences the student's success in language learning, namely the environment characteristic. Environment characteristic consist of teacher, material classroom management, students, physical condition and classroom climate.

Rasyid (1993) in Erlina (1998: 1) states that one of the factors that must be implemented in teaching and learning process is that the teacher must be a professional. In this case, teacher plays many roles in classroom. These include such functioning learning activity developing material, managing, and control behavior, evaluating students learning and 
acting as a model. Further, classroom teacher must establish successful learning environment. The effective aspect of it include students perception about learning, feeling about the teacher and learning routines, all of which contribute positively and negatively to the learning atmosphere.

Based on the background above, the writer tries to discuss the student's attitude toward English classroom environment and the subject of the study is the second year students of MTs Negeri Model Makassar.

Based on the background above the writer aimed at finding out the student attitude toward English Classroom Environment in the second year students of MTs Negeri Model Makassar, the research formulated the research question as follows:

1. How is the students' attitude toward their English teacher?

2. How is the students' attitude toward English material?

3. How is the students' attitude toward English classroom management?

The objectives of this study are point forward as follows:

1. To find out the attitude of the second year students of MTs Negeri Model Makassar toward their English teacher.

2. To find out the attitude of the second year students of MTs Negeri Model Makassar toward English material.
3. To find out the attitude of the second year students of MTs Negeri Model Makassar toward English classroom management

The results of the research is expected to be useful information for the teacher, the headmaster and the decision marker of English language instruction at junior high school in Makassar generally and especially in MTs Negeri Model Makassar in making decision and development related to English instruction.

\section{REVIEW OF RELATED LITERATURE}

\section{Attitude}

In connection with learning, if the students have positive attitude toward a lesson, they will always study lesson and probably. They will attend the class regularly. The degree of success of learners can be expected to attain in their learning activities depends on great measure upon their own attitudes.

According to M Ahzarin R. B Anaji and L Arisa H Eiphetz, 2010. The group that gave this concept scientific birth in the early 20th century chose attitude as the name to refer to such preferences. So intently did the pioneers focus on a study of attitudes that the field of social psychology came to be synonymous with the study of this single concept (Bogardus, 1931; Thomas \& Znaniecki, 1918). It is, in this sense, the oldest of the children displayed in the family photographs that constitute these handbooks, the oldest child that is assured front and center seat in every previous photograph taken (see 
Gilbert, Fiske, \& Lindzey, 1998; Lindzey, 1954; Lindzey \& Aronson, 1969, 1985; Murchison, 1935).

Aiken (1988: 303) states that attitude is a learned predisposition to respond positively or negatively to a certain object, situation, institution, or person.

Hornby (1992: 92) states that attitude is the way of thinking or behaving someone or something. While Morgan (1961: 562) points out that attitude is a tendency to respond positively or negatively to certain object, person or situation. This definition indicates those attitudes are directed to certain object. Attitude will emerge in the object concerned are valuable or pleased. On the contrary, in the objects concerned are invaluable, negative attitude seem appear.

These definitions indicate that attitudes are directed to certain objects. Attitudes toward object, person, situation can be emerged in the positive or negative. Positive attitudes will emerge if the objects concerned are valuable or pleased. On the contrary, if the object concerned is invaluable or unpleased negative attitude seem to appear. The definition above also given indication that attitude refers to action, readiness to responds to person and objects whether people like or dislike. The process can influence individual's behaviour. In other words, attitudes are tendencies to give responses either action or other ways toward certain object. The responses are determined by how individual evaluates the present object.
Attitude are also much determined by one's behaviour. Furthermore, attitude will reflex one's personality. Someone who has good attitudes toward the things will directly show. Likewise, if someone has bad attitudes or toward something tends to show his or her negative behaviour or respond toward the things.

In this research, the writer emphasizes those which are closely related to the student's attitude in learning process.

a. Interest

Interest is one of psychological aspects that can influence students learning and many experts have states their point of view as the following: Aiken (1988:305) defines an interest is a feeling of preference connecting one's own activities. Being interested in something simply means that the person spends time thinking about or reacting to it, regardless of whether those thoughts and reaction are positive or negative.

By paying close attention to the two definition above, interest has a positive attitudes or other feeling towards something will directly our motivation to know thing. Consequently, our attention is focused on the object concern.

In connection with learning, if a student has a good interest toward a lesson, they will always try to know and understand the lesson, and enjoy all the activities relate to that lesson. Interest can formulate students' personal disciplines in attending English lesson. From this point of view, it can be said that student's 
attitude may be formed because they have interest towards a certain lesson.

Aswar (1988 in Muhrama 2004: 6) suggest that attitude consists of three components namely cognitive or action component of the attitude is that aspect based on the beliefs or knowledge. Someone belief based on his knowledge about thing or attitude towards things. Affective component refers to emotional judgment of someone toward the attitude object. The emotional judgment will develop his feeling about the object whether positive or negative. Finally the action component of attitude shows how the persons will act to the attitude object. The way of someone to act to certain stimulant or object I determined by his belief and feeling toward it.

\section{b. Motivation}

Motivation also, the most important factor affecting the student's success in learning. Brown (1987: 144) states that motivation is commonly thought of as an inner drive, impulse, emotion or desire that moves one to a particular action. More specifically, the students have needed or drives that are more less innate, their intensity is environmentally conditioned. According to Harmer (1991: 157) motivation is some kind of internal dive that encourages somebody to pursue a course of action. If we perceive a goal and if that goals are sufficiently attractive, we will be strongly motivated to do whatever is necessary to reach that goal. There are two main category of the motivation according to Harmer (1991: 158), they are:
1) Extrinsic motivation

Extrinsic motivation is concerned with factors outside the classroom. It is divided two categories:

a) Integrative Motivation

Integrative motivation refers to whether the students need to be attracted by the culture.

b) Instrumental Motivation

This term describes a situation in which students' belief that mastery of the target language will be instrumental in getting them into mutually job, position or status.

2) Intrinsic Motivation

Intrinsic Motivation which is concerned with what takes places inside the classroom. Factors that affecting intrinsic motivation are:
a) Physical condition
b) Method
c) Teacher
d) Success

The factors of the intrinsic motivation related to the classroom environment that will be presented on the next page.

\section{Behaviour}

Hornby (1992:96) states that behave is act or conduct oneself in specific way, way of acting or functioning. From the definition above, we can conclude that behave or behaving is the action component which refer to one's act toward thing, whether he respond positively (favourably) or negatively (unfavourably). One may take and play 
football which means that he responds positively (favourably) toward the ball or throw it away and only sit down without effort in regard that he responds it negatively (unfavourably).

In learning and teaching English is not directly focusing the students contact with the material. The teacher has to know the students fell about learning English, what the students need, do they have positive view of English teaching and many consideration that have to handle, as Harmer (1991: 224) states that teacher needs know the considerable amount his students.

The motivation of the students to learn is taught to be determined by both his attitude and type of orientation he has toward learning a second language. Spolsky (1989) states that the learner's attitude affects his development of motivation. The more positive of the learners' attitude toward the object, the highest motivation he has to study the object.

English classroom environment is intended to surrounding of language learning that is intentional formally. It is managed by the teacher.

Nunan (1989: 8) states that Environment which is closely connected which mode, refers to the learning actually take place. It might be a conventional classroom in a language centre, a community class, an industrial or occupation setting, a self-access learning centre and so on. Until comparatively recently, it was assumed that learning would take place inside conventional classroom.

1) Teacher
One of the most important elements in the learning situations is the teacher themselves. Their skill and personality are instrumental in creating the conditions for learning.

The classroom environment must be perceived positively than negatively. This means that it must be planned just an instructional components of teaching are planned. Through planning a teacher can anticipate and avoid problems.

Nunan (1989: 84) states that the teacher roles are related to the following issues:

a) The types of function teacher are expected to students, example whether that of practice director, counsellor or model.

b) The degree of control the teacher has over how learning takes place.

c) The interaction pattern that develop between teacher and learners.

The teacher as teacher is necessary only when the class is attempting to resolve a language problem, for it is only in this situation that the teacher is automatically presumed to possess more knowledge than the students.

A teacher must be qualified and competent for successful teaching. As Hamacheck in Jarolemek (1976:3132 ) identifies several traits that good teachers possess:

a) The view teaching as basically-first and last a human process. Such teacher have a sense of humour, they can emphasize with students, they are fair, they are flexible, 
they are democratic than peers. Their classroom reflects an openness and sense of mutual trust.

b) They feel good about themselves and they have a positive attitude/view of other. Thus, they identify with people rather than withdrawing from them. They feel worthy in what they believe to be significance human service.

c) They are knowledgeable and well informed on a wide range subject. They have a respect for knowledge, and they believe strongly that their pupils must also learn respect it as vital force in happy and productive life.

d) They are able to communicate effectively. They understand that their communication process includes more than presentationit also provides for discovery and interaction with other as it provides for development of personal meaning. They employ a comprehension repertoire of teaching modes that produce affective as well as cognitive gains in their pupils.

The important roles of the teacher in any situation activity have been discussed by the educational experts for a long time. Abdurrahman (1986) quoted Finocchiacr's opinion as follows: "The personality of the teacher coupled with his attitude towards his pupil, his colleges, and his supervisor and his work will determine the extent to which any program, no matter how well formulated will be carried out. Naturally, the general teaching skill of instructors his special training in the field of language teaching and linguistics ability will also affect the learning situation".

\section{2) Materials}

The materials that facilitate language learning are the material used typically with the subject matter of the content course.

If we pay attention to the rules of the teachers and materialist, we can find the relationship both of them. The teachers are the actor of the presentation of the materials to the student, while the materials them salver are something that the teachers will present to the students. Before the teacher teach, it necessary for them to make a good presentation. The following section should be presented to the students:

a) What material will be presented to the students

b) What method are accurate to be applied for certain material

c) What media which is suitable to be used

d) The material should be based on the students' progresses of the study.

Richards (2001: 200) states that the role of instructional material is important part in creating opportunities for students. The same materials can be used in other types of lessons but variations are required in how the materials are used.

3) Classroom management 
Learning a language, like the learning anything else, is essentially an individual achievement, an exploitation of the capacities of the mind to make sense of the environment. But typically this private process takes places in the public context of the classroom. The typically this private process take places in the private process take places in public context of the classroom. The typically this private process take places in the class, and the activities which are to set the process in train are determined by the teacher. There can be little doubt that skill in classroom management or control is a major factor contributing to the success of the teacher.

Management, when one speaks of management, one means that there is something to manage and that someone does the managing. To manage means that one person is in charge-the manager directs, administers succeeds in getting a job done. In the context of the classroom, the teacher is a classroom manager; he is directing, administering and succeeding in getting the job of teaching accomplished, in accordance with recognized educational and physical principles.

Control, the term control is often used a convenient catch-all for what is more correctly called classroom management. An objectionable aspect of the control concept is the implication that is the teacher who is wholly responsible for maintaining an orderly classroom environment. This runs to the idea that children need to learn responsible habits of selfdirection. They need learn to conduct themselves properly, not to please the teacher, but because in so doing they develop greater maturity and independence. Learning to take care of one-self should be an important outcome of the school. It is not likely to be achieved if the behaviour of the learner is always controlled by the teacher.

Discipline, the term discipline like is often incorrectly used to mean various aspects of classroom management. "She has good discipline" usually means that the teacher maintains an orderly, probably a strict, classroom. Discipline also connotes punishments. "Strong discipline" is used to describe teacher behaviour that is frigid, firm unbending.

When the teacher says, "Anyone who leaves the room without permission will be discipline, "she means that the offender will be punished in order to teach him not do it again. In this sense, discipline means both punishment and corrective treatment.

Penny Ur (1996: 136) states that characteristics of classroom discipline are:
a) Learning is taking place
b) It is quiet
c) The teacher is in control
d) Teacher and students are cooperating smoothly
e) Teacher is motivated 
f) The lesson is proceeding according to plan

g) Teacher and students are aiming for the same objective

h) The teacher has natural charismatic

\section{Research Method}

The method used in this research was a descriptive method. It described the student's attitude towards their English teacher, English material, and English Classroom management.

\section{Variable}

The study used one variable.

A linear equation in one variable is an equation that can be written in the form $a \times b c+=$, where $a, b$, and $c$ are real numbers. Linear equations are also first-degree equations because the exponent on the variable is understood to be 1 . The variable was the attitude of the students toward English teacher, English material, and English classroom management

\section{Population and Sample}

The population of the study was the second students of MTs Negeri Model Makassar in academic year 2018/2019. It consists of 365 students from Nine classes. Each class consists of 40-45 students.

The sample technique of this study was random sampling, in which the writer took 50 students randomly from nine classes. It means that the number of sample is 50 students.

\section{Instruments of the study}

The instruments used to collect the data were questionnaire. The questionnaire used to measure the students' attitude toward English teacher, English material and English classroom management.

Furthermore, the questionnaire consists of 45 items. 15 items to know the students' attitude toward English teacher, 15 items to know the students' attitude toward English material and 15 items to know the students' attitude toward English Classroom management. The questionnaire related to the students' interest (item 1 to 5 ), the students' motivation (item 6 to 10) and the students' behaviour (11 to 15). The item concerned with nine positive statements and six negative statements. The questionnaire is scored by employing Likert scale. The students were answer 45 items on a five point scale ranging from strongly agree to strongly disagree.

4. Procedure of Collecting Data

The data was collected by following procedures:

a. The writer contracted the teacher of the class, and then the writer invited the students.

b. The writer distributed the questionnaires to the students.

c. The writer explained to the students how to do the questionnaire. 
d. The students were given 90 minutes to answer the questionnaire.

5. Technique of Data Analysis

The writer collected the data from the questionnaire and analysed to find out the students' attitude toward their English teacher, English material and English Classroom management.

To analyze the questionnaire, score is classified as follow:

Since questionnaire consists of 15 items, the score is:

$15 \times 5=75$ is maximum score (positive)

$15 \times 3=45$ neutral

$15 \times 1=15$ undecided sc (negative). (John, W. Best. 19 197)

If the mean score of the students' 0 up to 15 , it indicates the studentc' attitude is negative, 16 up to indicates the students' attitude neutral while 46 up to 75 indicates students' attitude is positive.

b. The rate percentage of the stude

$$
\mathrm{P}=\frac{F Q}{N} \times 100 \%
$$

Where:

$\mathrm{P}=$ Percentage of the questionna $\mathrm{FQ}=$ The frequency items, $\mathrm{N}=\mathrm{T} \mathrm{c}$ sample. (Sudjana, 1991: 51)
FINDINGS AND DISCUSSION

1. Findings

a. The Students' Attitude toward their English Teacher.

\begin{tabular}{|l|}
\hline Positive attitude (46 -75) \\
\hline $\mathbf{3 9}$ students $(78 \%)$ positive \\
\hline $\mathbf{1 1}$ students $(22 \%)$ neutral \\
\hline none of the students negative \\
\hline positive interest \\
\hline $\mathbf{4 4}$ students $(\mathbf{8 3} \%)$ positive \\
\hline $\mathbf{6}$ students $(\mathbf{1 2} \%)$ neutral \\
\hline none of the students negative \\
\hline $\mathbf{4 0}$ students $(\mathbf{8 0} \%)$ positive \\
\hline $\mathbf{1 0}$ students (20\%) neutral \\
\hline none of the students negative \\
\hline positive behavior \\
\hline
\end{tabular}

b. The Students' Attitude toward their

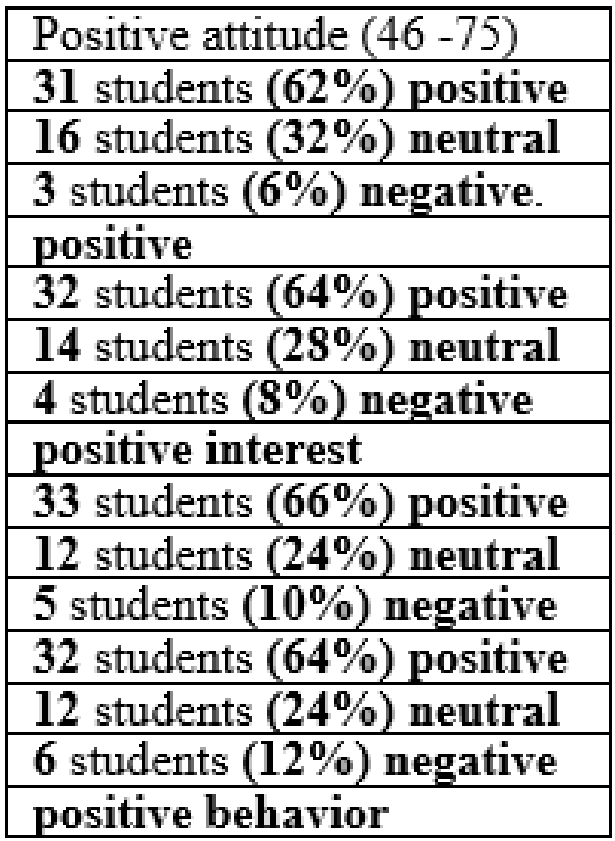




\begin{tabular}{|l}
\hline Neutral (16 up to 45$)$ \\
\hline $\mathbf{1 0}$ students (20\%) positive \\
\hline $\mathbf{3 8}$ students $(76 \%)$ neutral \\
\hline 2 students $(\mathbf{4} \%)$ negative \\
\hline neutral \\
\hline $\mathbf{1 0}$ students $(20 \%)$ positive \\
\hline $\mathbf{3 7}$ students $(74 \%)$ neutral \\
\hline $\mathbf{3}$ students $(6 \%)$ negative \\
\hline neutral interest \\
\hline
\end{tabular}

\section{Discussions}

a. The Students' Attitude toward their English Teacher

The students' attitude was assessed by using Likert scale. There were 15 items that two categories, 9 items were positive statement and 6 items were negative statement. The questionnaire related to students' attitude toward their English teacher (number 1 to 5), the students' motivation toward their English teacher (number 6 to 10), the students' behaviour toward their English teacher (number 11 to 15 ). The research is followed by 50 respondents. The questionnaire was successfully answered by respondents, there were 39 respondents got score 46 up to 75 were categorized as positive attitude and $\mathbf{1 1}$ respondents got score 16 up to 45 were categorized as neutral attitude and none of the respondents got negative attitude.

The mean score of the students' attitude toward their English teacher was $\mathbf{5 9 . 2 4}$, it is positive. John states that if the students' score 46 up to 75 , it can be categorized into positive. The writer had $\mathbf{2 9 6 2}$ for all score of the students (see appendix II A. I).

The writer found that most of the second year students of MTs Negeri Model Makassar had positive toward their English teacher. Though, some of the students had neutral English teacher and none of the students had negative English teacher as table 02.03, 04.05, 06 showed. In the students' interest toward their English teacher, (78\%) students had positive attitude, (22\%) students were neutral attitude. Then, in the students' motivation toward their English teacher, (88\%) students had positive attitude, (12\%) students were neutral. While in the students' behaviour toward their English teacher, $(\mathbf{8 0} \%)$ students had positive attitude, (20\%) students were neutral attitude. From this data, the writer concluded that the highest score of the students' attitude toward their English teacher was the students' motivation, then the students' interest and the last one was the students' behaviour.

b. The Students' Attitude toward English material

The students' attitude was assessed by using Likert scale. There were 15 items that two categories, 9 items were positive statement and 6 items were negative statement. The questionnaire related to students' interest toward English material (number 1 to 5), the students' motivation toward English material 
(number 6 to 10), the students' behaviour toward English material (number 11 to 15 ). The research was followed by 50 respondents. The questionnaire was successfully answered by respondents, there were 31 respondents got score 46 up to 75 were categorized as positive, 16 respondents got score 16 up to 45 were categorized as neutral attitude, and 3 respondents got score 5 up to 15 were categories as negative attitude.

The mean score of the students' attitude toward their English material was 53.64, it is positive. The decision was taken from standard score of Best. W.John.1982:197, states that if the students' score 46 up 75 , it can be categorized into positive. The writer had $\mathbf{2 6 8 2}$ for all score of the students (see appendix II A. 2).

The writer found that most of the second year students of MTs Negeri Model Makassar had positive toward English material. Even though, some of the students had neutral English material and negative English material as table 07, 08, 09, 10, 11 showed. In the students' interest toward English material, (64\%) students had positive attitude, (28\%) students had neutral attitude, and (8\%) students had negative attitude. Then, in the students' motivation toward English material, (66\%) students had positive attitude, (24\%) students were neutral, and (10\%) students have negative. while in the students behaviour toward English material, (64\%) Students had positive attitude, (24\%) students were neutral and (12\%) had negative attitude. From this data, the writer concluded that the highest score of the students' attitude toward English material was the students' interest, then the students' motivation, and the last one was the students' behaviour.

c. The Students' Attitude toward English Classroom management

The students' attitude was assessed by using Likert scale. There were 15 items that two categories, 9 items were positive statement and 6 items were negative statement. The questionnaire related to students' interest toward English classroom management (number 1 to 5), the students' motivation toward English classroom management (number 6 to 10), the students' behaviour toward English classroom management (number 11 to 15 ). The research was followed by 50 respondents. The questionnaire was successfully answered by respondents, there were $\mathbf{1 0}$ respondents got score 46 up to 75 were categorized as positive, 38 respondents got score 16 up to 45 were categorized as neutral attitude, and 2 respondents got score 5 up to 15 were categorized as negative attitude.

The mean score of the students' attitude toward English classroom management was $\mathbf{3 9 . 8}$, it is neutral. The decision was taken from standard score of Best. W.John.1982:197, states that if the students score 16 up 45 , it can be categorized into positive. The writer had $\mathbf{1 9 9 0}$ for all score of the students (see appendix II A. 3). 
The writer found that most of the second year students of MTs Negeri Model Makassar had neutral toward English classroom management. Even though, some of the students had positive and negative English classroom management as table 12 , $13,14,15,16$ showed. In the students' interest toward their English classroom management, (20\%) students had positive attitude, (76\%) students were neutral attitude, and (6\%) students had negative attitude. Then, in the students' motivation toward English classroom management, (24\%) students had positive attitude, (70\%) students were neutral, and $(6 \%)$ students had negative attitude. While in the students' behaviour toward English classroom management, (18\%) students had positive attitude, (76\%) students were neutral, and (6\%) had negative attitude. From these data, the writer concluded that the highest score of the students' attitude toward English Classroom management was the students' behaviour, then the students' motivation, and the last one was the students' interest.

From three categories measured above, the students' attitude toward their English teacher showed that the mean score is positive (59.24), it means that the teacher success in transferring knowledge to the students. Secondly, the students' attitude toward English material showed that the mean score is positive (53.64), it means that the students enjoyed the English materials that given to them, and the last the students' attitude toward English classroom management showed that the mean score is neutral (39. 8), it means that, most of the students can receive the climate of the classroom as a suggestion in learning English.

\section{CONCLUSION AND SUGGESTION}

\section{Conclusion}

Based on the result and discussion of the previous chapter, the writer comes to the following conclusion:

a. The second year students of MTs Negeri Model Makassar in academic year 2018/2019 have "positive" attitude toward their English teacher.

b. The second year students of MTs Negeri Model Makassar in academic year 2018/2019 have "positive" attitude toward English material.

c. The second year students of MTs Negeri Model Makassar in academic year 2018/2019 have "Neutral" attitude toward English classroom management.

\section{Suggestion}

Based on the result of interpretative analysis, the following suggestions are forwarded:

a. English classroom environment is an important factor in teaching at MTs Negeri Model Makassar

b. The head office of national education department should give training for English teacher at MTs Negeri Model Makassar in 
order they get more skills and pay attention to the classroom environment's factor

c. To the English teachers, they must be creative in teaching
English, so the students can be motivated in learning English.

d. To the students, they must make English as interesting subject so that can give benefit to the future.

\section{BIBLIOGRAPHY}

Aiken, Lewis. R. 1988. Psychological Teaching and Assessment. Massachusets: Jhon Paul-Henri Aliyn.

Brown, Douglas.1987. Principles of Language Learning and Teaching. San Francisco State University.

Cooper, Mames M, et. al. 1977. Classroom Teaching Skills. Toronto: D. C. Health company.

Cazden, Courtney. B, et. al. 1972. Function of Language in the Classroom. New York and London: Columbia University.

David Crystal and Robert Henry Robins, 2018. Encyclopedia Britannica.

Gay, L.R. 1981. Educational Research. Florida: Bell and Havel Company.

Harmer, Jeremy.1991. The Practice of English Language Teaching. London: Logmant.

Heneson, E. Marlene, Lynn L. Morris, Carol T fitz. 1997. How to Measure Attitude. London: sage publications, International Educational and professional publisher.

Hornby, A. S. et. Al. 1992. The Advanced Learner's Dictionary of Curent English. London: Oxford University Press.

John, W. Best. 1982. Metodologi Penelitian Usaha Nasional. Surabaya, Indonesia.

Malamah, Ann. 1987. Classroom Interaction. Thomas Oxford University Press

M Ahzarin R. B Anaji and L Arisa H Eiphetz, 2010. Integration theory and attitude change. Psychological Review.

Nunan, David. 1991. Language Teaching Methodology. Macquarie University.

Rabecca., Edwar. 1972. Classroom Techniques. Foreign languages and English as a Second Langauge. 
Rasyid, Muhammad Amin.1992. Developing Communicative Competence through Topics of Interest and Learnig Style Using the Integrared Skill Approach. Dissertation. Ujung Pandang: Post Graduate programme, Hasanuddin University.

Sudjana, p.et.al. 1989. Penelitian Pendidikan. Sinar Baru : Bandung.

Ur, Penny. 1996. A Course In Language Teaching. University Press: Combridge. Wikipedia, the free encyclopaedia, 